\title{
Energy analysis of a stepped cascade solar still connected to photovoltaic thermal collector
}

\section{E. Hedayati-Mehdiabadi, F. Sarhaddi* and F. Sobhnamayan}

\author{
Research Laboratory of Renewable Energies and Electromagnetic Fluids, \\ Department of Mechanical Engineering, University of Sistan and Baluchestan, \\ Zahedan, Iran \\ Phone: +98 54 31136465; Fax: +98 5433447092 \\ *E-mail: fsarhaddi@eng.usb.ac.ir
}

\begin{abstract}
In this paper, the performance evaluation of a stepped cascade solar still connected to photovoltaic thermal (PV/T) collector was carried out. The governing equations of problem was a set of initial value ordinary differential equations which were obtained by writing energy balance for the various components of solar still system (i.e. glass cover, brackish water, absorber plate, and PV/T collector). The numerical model of problem was solved by the 4th-order Runge-Kutta method under real climatic conditions sample. The validation of numerical model was carried out by the experimental data of previous literature. Parametric studies showed that the energy efficiency of stepped cascade solar still maximised in the desired brackish water flow of $0.03 \mathrm{~kg} / \mathrm{min}$ and the PV/T collector area of $1.3 \mathrm{~m}^{2}$. The daily energy efficiency and accumulated freshwater were about $26 \%$ and $5.71 \mathrm{~kg} /\left(\mathrm{m}^{2}\right.$.day), respectively. An increase of about $20 \%$ was obtained in freshwater productivity by the connection of PV/T collector to the stepped cascade solar still. Also, $\mathrm{PV} / \mathrm{T}$ collector, in addition to providing pumping power, can supply electrical power of about $0.918 \mathrm{~kW} /$ day for other uses. In order to produce freshwater during the night time, the usage of the phase change materials below the absorber plate was suggested.
\end{abstract}

Keywords: Solar still; stepped cascade; PV/T collector; energy efficiency.

\section{INTRODUCTION}

In recent years, many parts of the world face freshwater scarcity crisis. Three-quarters of the Earth's surface is covered by oceans and seawater. However, the sources of drinking water are limited and include 3 percent of all the Earth's water. Only one percent of drinking water sources is available and the rest of them are frozen in polar glaciers (2\%) [1]. Some industrial processes such as the ozonation of wastewater [2] , wastewater purification by graphene oxide [3], wastewater purification by biological oscillatory flow reactor [4], wastewater filtration by nano tube bundles filters [5, 6], etc. are the main candidates for freshwater production from wastewater sources. Generally, the mentioned processes are used for wastewater purification or freshwater production in an industrial scale and not used for freshwater production in a domestic scale due to high cost and high energy consumption. Most of the arid and remote areas of the world have high solar potential and abundance of undesirable groundwater resources [7]. Therefore, in these regions, the direct solar desalination can be an appropriate way to produce freshwater in a domestic scale. Two common types of direct solar desalination system include stepped 
cascade solar still and basin solar still. The freshwater production efficiency of stepped cascade solar still is more than the basin solar still [8]. Its main reasons are thin layer of brackish water, the forced mode of brackish water flow and higher evaporation rate in the stepped cascade solar still. However, the need for an external electrical source for water circulation is the main deficiency of the stepped cascade solar still. In order to overcome this shortage, the photovoltaic thermal (PV/T) collector can be connected to the cascade solar still. In addition to providing electrical power, the PV/T collector also plays the role of brackish water preheater and increases the average temperature of brackish water at the entrance to the solar still. On the other hand, the electrical performance of the PV/T collector improves by cooling the brackish water. Figure 1 shows the photograph of a stepped cascade solar still, basin solar still and PV/T collector.

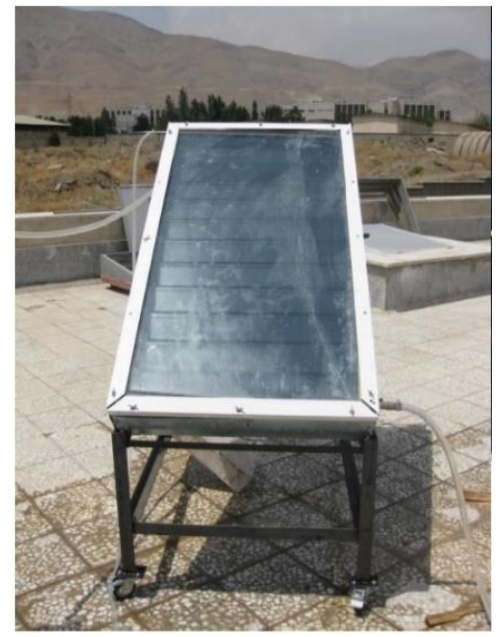

(a)

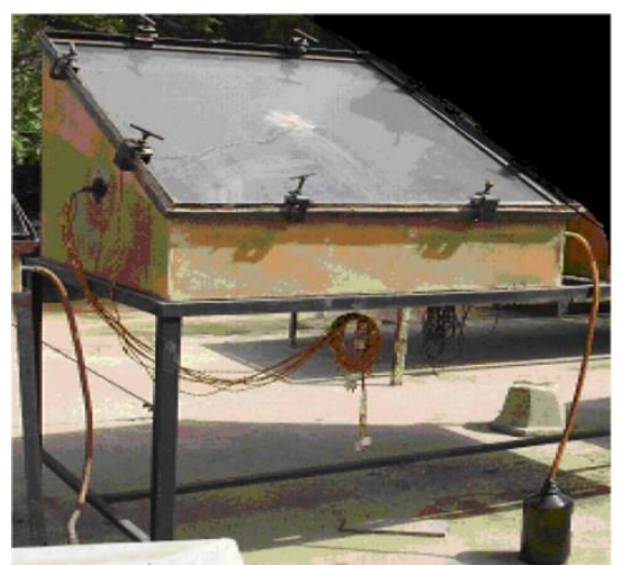

(b)

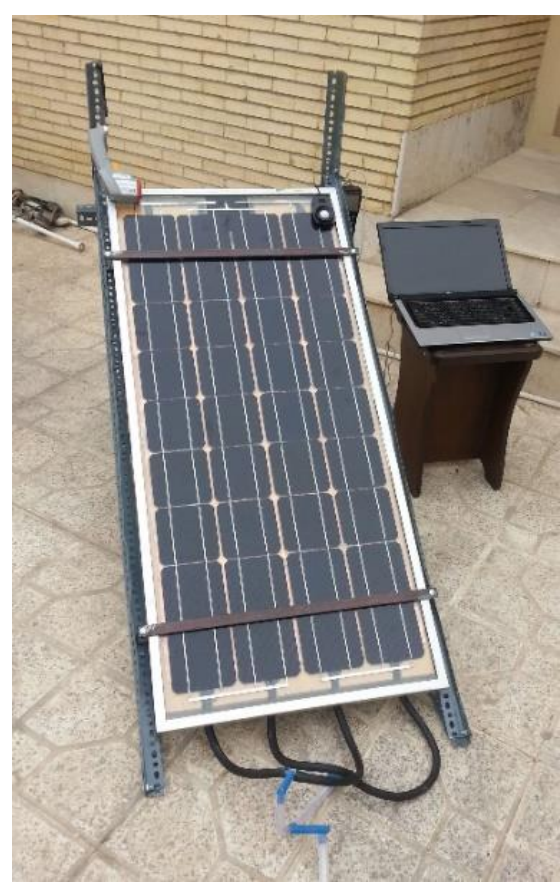

(c)

Figure 1. (a) Stepped cascade solar still [9]; (b) Basin solar still [10]; (c) PV/T collector [11]. 
The performance evaluation of stepped cascade solar still connected to PV/T collector can provide the criteria for improving freshwater production efficiency. The study on the performance assessment of cascade solar stills has been done by many researchers. The start of research on cascade solar stills was done in the first half of the 1970s by Headley [12]. He designed a cascade solar still for distilled water production. His design gave higher freshwater productivity than the conventional basin solar stills due to short distillation gap, high condensing ratio and low thermal inertia. Sadineni et al. have shown experimentally that the freshwater productivity of a cascade solar still is $20 \%$ more than the basin solar still [8]. Dashtban and Farshchi Tabrizi have demonstrated that the reduction of air gap in the cascade solar still improved the freshwater productivity by $35 \%$ [13]. Alaudeen et al. have pointed out that the connection of flat plate collector to stepped solar still caused a significant increase in freshwater productivity [14]. Hansen et al. have investigated the usage of various wick materials on the performance of an inclined type solar still, experimentally [15]. The wick materials included wood pulp paper wick, wicking water, coral fleece fabric and polystyrene sponge. They reported that the inclined type solar still, with coral fleece and weir mesh-stepped absorber plate had, more productivity. Its freshwater productivity was 4.28 1/day. El-Samadony et al. have studied the effect of radiation shape factor between hot saline water and glass cover on the performance of a stepped solar still, theoretically [16]. They found that freshwater productivity was very sensitive to the radiation shape at low solar insolation and/or high glass cover inclination angle. Sathyamurthy et al. have investigated the effect of various operating parameters (i.e. mass flow, feed water temperature, internal heat transfer coefficient, absorber plate temperature, and baffle plates) on the freshwater productivity of an inclined solar still [17]. They have introduced a modified analytical model for the prediction of the average water temperature in stepped and weir cascade solar stills. Their results showed that the insert of baffle plates on absorber plate increased freshwater productivity due to the higher absorption of solar radiation intensity. Bhalara et al. have designed, fabricated and tested a modified stepped solar still [18]. Their modification included fabricating steps on which small earthen lamps were placed. Their modification caused an increase of $326.66 \%$ in freshwater productivity. Saettone et al. have designed and studied a stepped solar still with internal reflective walls and attached a set of heat pipes [19]. The use of the set of heat pipes enhanced solar still performance by $32.4 \%$. Nagarajan et al. have investigated the performance of an inclined solar still with and without baffles[20]. Their results showed that the fresh water productivity of the solar still with baffles was1.68 times the fresh water productivity of the solar still without baffles. Abujazar et al. have done the efficiency evaluation of an inclined copper-stepped solar still experimentally [21]. They pointed out that the use of inclined trays in the stepped solar still increased the freshwater productivity to $605 \mathrm{~mL} / \mathrm{m}^{2}$. Rashidi et al. have investigated the effect of nanofluid on the productivity of a stepped solar still numerically [22]. Also, they have optimised the geometry of steps. Their results showed an enhancement of $22 \%$ in hourly productivity. The abovementioned literature review showed that the effects of various design and operating parameters (i.e. air gap [13], mass flow rate [7, 17], wick material [15], internal reflector [19], baffle [17, 20], inclined tray [21], steps geometry optimisation [22] and nanofluid [5, 6]) on the freshwater productivity of stepped cascade solar still have been investigated. However, the effect of PV/T collector connection to stepped cascade solar still to enhance freshwater productivity is not investigated. PV/T collector provides the pumping power and preheats the brackish water at the entrance of cascade solar still. Also, the electrical performance of PV/T collector improves by cooling the brackish water. 


\section{METHODS AND MATERIALS}

The present research is based on numerical simulation. The governing equations of problem were obtained by writing energy balance for the various components of solar still system (i.e. glass cover, brackish water, absorber plate, PV/T collector). A computer simulation programme was developed in order to solve the governing equations. Validation of numerical simulation was carried out. Finally, some parametric studies were carried out in order to investigate the effect of design and operating parameters on energy efficiency, freshwater productivity and electrical power output. Figure 2 shows the schematic view of stepped cascade solar still connected to PV/T collector.

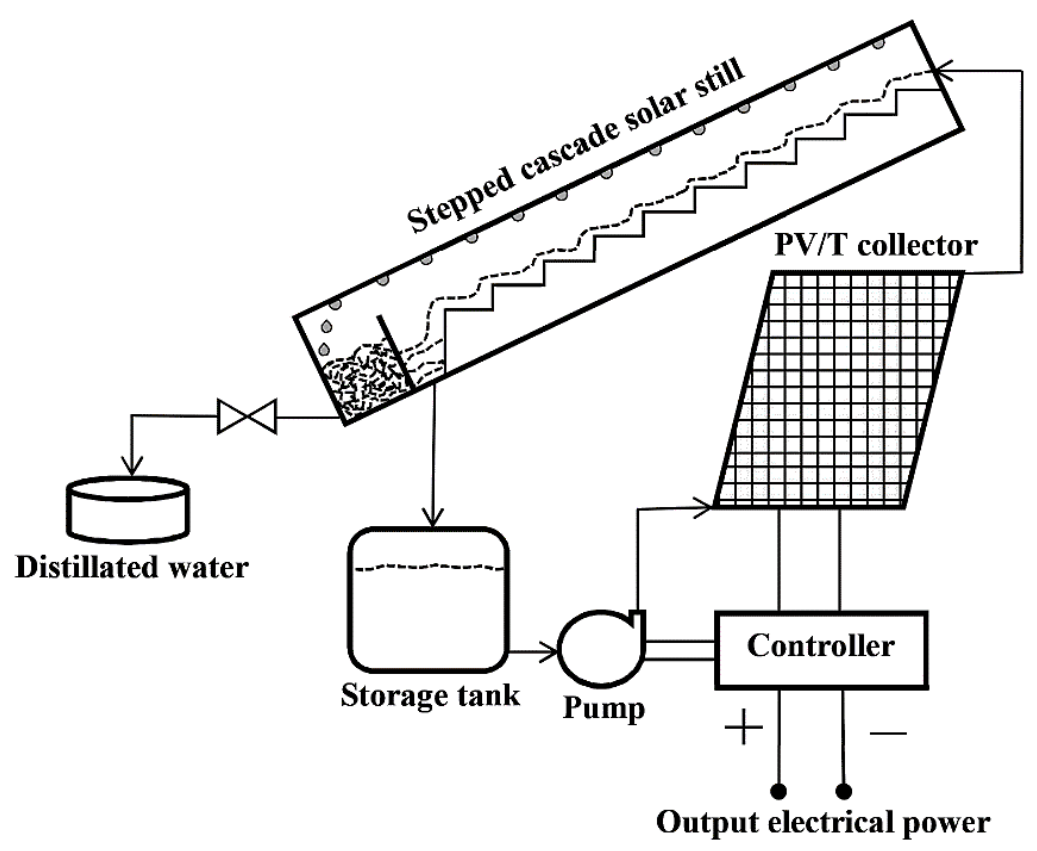

Figure 2. Schematic view of stepped cascade solar still connected to PV/T collector.

According to Figure 2, the pump flows the brackish water from storage tank to PV/T collector. The PV/T collector preheats the brackish water. Also, the electrical performance of photovoltaic cells improves by cooling the brackish water. Preheated brackish water is more heated in the cascade solar still. The heated brackish water is evaporated. The condensation of water vapor is done on glass cover and distillated water is produced. Photovoltaic cells provide the pumping power and the extra electrical power is stored for other usages.

\section{Energy Balance for Glass Cover}

The various energy rates in the control volume of glass cover is defined as follows [13, 17].

[Solar energy rate which is absorbed by glass cover] $+[$ Heat transfer rate from brackish water to glass cover] $=[$ Convection heat loss rate from glass cover to ambient $]+$ [Radiation heat loss rate from glass cover to sky]+[Stored energy rate in glass cover].

$$
\alpha_{\mathrm{g}} G_{\mathrm{s}} A_{\mathrm{g}}+h_{\mathrm{w}-\mathrm{g}} A_{\mathrm{w}}\left(T_{\mathrm{w}}-T_{\mathrm{g}}\right)=h_{\mathrm{c}, \mathrm{g}-\mathrm{a}} A_{\mathrm{g}}\left(T_{\mathrm{g}}-T_{\mathrm{a}}\right)+h_{\mathrm{r}, \mathrm{g}-\mathrm{sky}} A_{\mathrm{g}}\left(T_{\mathrm{g}}-T_{\text {sky }}\right)+m_{\mathrm{g}} C_{\mathrm{g}} \frac{d T_{\mathrm{g}}}{d t}
$$


where $T_{\mathrm{g}}, T_{\mathrm{w}}, T_{\mathrm{a}}, T_{\text {sky }}, G_{\mathrm{s}}, m_{\mathrm{g}}, C_{\mathrm{g}}, A_{\mathrm{g}}, A_{\mathrm{w}}$ and $\alpha_{\mathrm{g}}$ are the glass cover temperature, brackish water temperature, ambient temperature, sky temperature, solar radiation intensity on solar still, mass of glass cover, heat capacity of glass cover, area of glass cover, area of water surface and absorptivity of glass cover, respectively. Also, $h_{\mathrm{w}-\mathrm{g}}$, $h_{\mathrm{c}, \mathrm{g}-\mathrm{a}}$ and $h_{\mathrm{r}, \mathrm{g}-\mathrm{sky}}$ are the overall heat transfer coefficient from water to glass cover, convective heat transfer coefficient from the glass cover to ambient and radiative heat transfer coefficient from glass cover to sky, respectively. It should be mentioned that the related heat transfer coefficients are given in the APPENDIX.

\section{Energy Balance for Brackish Water}

The various energy rates in the control volume of brackish water is defined as follows $[13,17]$.

[Solar energy rate which is absorbed by brackish water]+[Convection heat transfer rate from absorber plate to brackish water]+[Useful heat gain of PV/T collector] $=[$ Heat transfer rate from brackish water to glass cover] $+[$ Stored energy rate in brackish water]

$$
\tau_{\mathrm{g}} \alpha_{\mathrm{w}} G_{\mathrm{s}} A_{\mathrm{w}}+h_{\mathrm{p}-\mathrm{w}} A_{\mathrm{p}}\left(T_{\mathrm{p}}-T_{\mathrm{w}}\right)+Q_{\mathrm{c}}=h_{\mathrm{w}-\mathrm{g}} A_{\mathrm{w}}\left(T_{\mathrm{w}}-T_{\mathrm{g}}\right)+m_{\mathrm{w}} C_{\mathrm{w}} \frac{d T_{\mathrm{w}}}{d t}
$$

where $T_{\mathrm{p}}, A_{\mathrm{p}}, m_{\mathrm{w}}, C_{\mathrm{w}}, \alpha_{\mathrm{w}}, \tau_{\mathrm{g}}$ and $Q_{\mathrm{c}}$ are the absorber plate temperature, area of absorber plate, mass of brackish water, heat capacity of brackish water, absorptivity of brackish water, transmissivity of glass cover and the useful heat gain of PV/T collector, respectively. Besides, $h_{\mathrm{p}-\mathrm{w}}$ is the convective heat coefficient between absorber plate and brackish water and it is given in Table 1.

Tiwari and Sodha [23] have given an expression for the useful heat gain of PV/T collector as follows

$$
\begin{gathered}
Q_{\mathrm{c}}=F_{R} A_{\mathrm{c}}\left[h_{\mathrm{p} 1} h_{\mathrm{p} 2}(\alpha \tau)_{\mathrm{eff}} G_{\mathrm{c}}-U_{\mathrm{c}}\left(T_{\mathrm{w}}-T_{\mathrm{a}}\right)\right] \\
F_{R}=\frac{\dot{m}_{\mathrm{w}} C_{\mathrm{w}}}{U_{\mathrm{c}} A_{\mathrm{c}}}\left[1-\exp \left\{-\frac{F^{\prime} U_{\mathrm{c}} A_{\mathrm{c}}}{\dot{m}_{\mathrm{w}} C_{\mathrm{w}}}\right\}\right]
\end{gathered}
$$

where $A_{\mathrm{c}}, G_{\mathrm{c}}, U_{\mathrm{c}}, \dot{m}_{\mathrm{w}}, F_{R}, F^{\prime}$ and $(\alpha \tau)_{\text {eff }}$ are the PV/T collector area, solar radiation intensity on $\mathrm{PV} / \mathrm{T}$ collector, overall heat loss coefficient of PV/T collector, the mass flow rate of brackish water in PV/T collector, heat removal factor, fin efficiency factor and the product of effective absorptivity and transmissivity, respectively. Also, $h_{\mathrm{p} 1}$ and $h_{\mathrm{p} 2}$ are the penalty factors. They are given in Table 1.

\section{Energy Balance for Absorber Plate}

The various energy rates in the control volume of absorber plate is defined as follows [13, 17].

[Solar energy rate which is absorbed by absorber plate] $=$ [Convection heat transfer rate from absorber plate to brackish water]+[Bottom heat loss rate from absorber plate to ambient $]+[$ Stored energy rate in absorber plate] 


$$
\tau_{\mathrm{g}} \tau_{\mathrm{w}} \alpha_{\mathrm{p}} G_{\mathrm{s}} A_{\mathrm{p}}=h_{\mathrm{p}-\mathrm{w}} A_{\mathrm{p}}\left(T_{\mathrm{p}}-T_{\mathrm{w}}\right)+h_{\mathrm{p}-\mathrm{a}} A_{\mathrm{p}}\left(T_{\mathrm{p}}-T_{\mathrm{a}}\right)+m_{\mathrm{p}} C_{\mathrm{p}} \frac{d T_{\mathrm{p}}}{d t}
$$

where $\alpha_{\mathrm{p}}, \tau_{\mathrm{w}}, m_{\mathrm{p}}, C_{\mathrm{p}}$ and $h_{\mathrm{p}-\mathrm{a}}$ are the absorptivity of absorber plate, transmissivity of brackish water, mass of absorber plate, heat capacity of absorber plate and overall heat loss coefficient from absorber plate to ambient, respectively.

Table 1. Design parameters of cascade solar still and PV/T collector [7, 11, 13, 17, 23].

\begin{tabular}{llll}
\hline \multicolumn{2}{c}{ Cascade solar still } & \multicolumn{2}{c}{ PV/T collector } \\
\hline Parameter & Value & Parameter & Value \\
\hline$A_{\mathrm{p}}$ & $0.72 \mathrm{~m}^{2}$ & $A_{\mathrm{c}}$ & $0.77 \mathrm{~m}^{2}$ \\
$A_{\mathrm{w}}$ & $0.45 \mathrm{~m}^{2}$ & $T_{\mathrm{a}, \mathrm{ref}}$ & $25{ }^{\circ} \mathrm{C}$ \\
$A_{\mathrm{g}}$ & $0.53 \mathrm{~m}^{2}$ & $\eta_{\mathrm{el}, \mathrm{ref}}$ & 0.1 \\
$m_{\mathrm{g}}$ & $4.1 \mathrm{~kg}$ & $h_{\mathrm{p} 1}$ & 0.8772 \\
$m_{\mathrm{w}}$ & $3.9 \mathrm{~kg}$ & $h_{\mathrm{p} 2}$ & 0.9841 \\
$m_{\mathrm{p}}$ & $4.1 \mathrm{~kg}$ & $(\alpha \tau)_{\mathrm{eff}}$ & 0.66 \\
$C_{\mathrm{g}}$ & $800 \mathrm{~J} / \mathrm{kg}^{\circ} \cdot \mathrm{C}$ & $F^{\prime}$ & 0.895 \\
$C_{\mathrm{w}}$ & $4190 \mathrm{~J} / \mathrm{kg} .{ }^{\circ} \mathrm{C}$ & $U_{\mathrm{c}}$ & $8.6 \mathrm{~W} / \mathrm{m}^{2} .{ }^{\circ} \mathrm{C}$ \\
$C_{\mathrm{p}}$ & $896 \mathrm{~J} / \mathrm{kg} .{ }^{\circ} \mathrm{C}$ & $U_{\mathrm{t}}$ & $9.24 \mathrm{~W} / \mathrm{m}^{2} .{ }^{\circ} \mathrm{C}$ \\
$h_{\mathrm{p}-\mathrm{a}}$ & $14 \mathrm{~W} / \mathrm{m}^{2} .{ }^{\circ} \mathrm{C}$ & $U_{\mathrm{T}}$ & $66 \mathrm{~W} / \mathrm{m}^{2} .{ }^{\circ} \mathrm{C}$ \\
$h_{\mathrm{p}-\mathrm{w}}$ & $109 \mathrm{~W} / \mathrm{m}^{2} .{ }^{\circ} \mathrm{C}$ & $U_{\mathrm{tT}}$ & $8.1028 \mathrm{~W} / \mathrm{m}^{2} .{ }^{\circ} \mathrm{C}$ \\
$\tau_{\mathrm{g}}=\tau_{\mathrm{w}}$ & 0.95 & $U_{\mathrm{w}}$ & $500 \mathrm{~W} / \mathrm{m}^{2} .{ }^{\circ} \mathrm{C}$ \\
$\alpha_{\mathrm{g}}=\alpha_{\mathrm{w}}$ & 0.05 & $\eta_{\mathrm{pump}}$ & 0.8 \\
$\varepsilon_{\mathrm{g}}$ & 0.88 & $C_{\mathrm{f}}$ & 0.38 \\
$\varepsilon_{\mathrm{w}}$ & 0.95 & & \\
$\alpha_{\mathrm{p}}$ & 0.9 & & \\
\hline
\end{tabular}

\section{Energy Efficiency}

The energy efficiency is defined as the ratio of net output (desired) energy rate to net input energy rate.

$$
\eta_{\mathrm{en}}=\frac{\text { Desired energy rate }}{\text { Net input energy rate }}
$$

According to Figure 1, the output desired energy rate of stepped cascade solar still connected to PV/T collector includes the rate of evaporative energy of solar still and the electrical power output of PV/T collector.

$$
E n_{\text {out,des }}=E n_{\mathrm{ev}}+E n_{\mathrm{el}}
$$

The rate of evaporative energy and freshwater productivity are given as [13, 17]. 


$$
\begin{gathered}
E n_{\mathrm{ev}}=h_{\mathrm{ev}, \mathrm{w}-\mathrm{g}} A_{\mathrm{w}}\left(T_{\mathrm{w}}-T_{\mathrm{g}}\right) \\
m_{\mathrm{ev}}=\frac{E n_{\mathrm{ev}} \times 3600}{h_{\mathrm{fg}}}
\end{gathered}
$$

where $h_{\mathrm{ev}, \mathrm{w}-\mathrm{g}}$ and $h_{\mathrm{fg}}$ are the evaporative heat transfer coefficient and the latent heat of water vaporisation, respectively. They are given in the APPENDIX.

The electrical power output of PV/T collector is given as [11, 23].

$$
E n_{\mathrm{el}}=A_{\mathrm{c}} G_{\mathrm{c}} \eta_{\mathrm{el}, \mathrm{ref}}\left[1-0.0045\left(T_{\mathrm{c}}-T_{\mathrm{a}, \mathrm{ref}}\right)\right]-\frac{\dot{m}_{\mathrm{w}} \Delta P}{\rho_{\mathrm{w}} \eta_{\mathrm{pump}}}
$$

It should be mentioned that the second term on the right-hand side of Eq. (10) is the consumed electrical power of pump to circulate brackish water through the solar still system. In Eq. (10), $\eta_{\mathrm{el}, \text { ref }}, T_{\mathrm{a}, \mathrm{ref}}, \Delta P, \rho_{\mathrm{w}}$ and $\eta_{\mathrm{pump}}$ are the electrical efficiency of PV module in reference conditions, ambient temperature in reference conditions, pressure drop through the system, density of brackish water and pump efficiency, respectively. Also, $T_{\mathrm{c}}$ is the PV/T collector temperature and it is given as [23]

$$
T_{\mathrm{c}}=\frac{U_{\mathrm{T}}\left[h_{\mathrm{p} 1}(\alpha \tau)_{\mathrm{eff}} G_{\mathrm{c}}+U_{\mathrm{tT}} T_{\mathrm{a}}+U_{\mathrm{w}} T_{\mathrm{w}}\right]}{\left(U_{\mathrm{t}}+U_{\mathrm{T}}\right)\left(U_{\mathrm{tT}}+U_{\mathrm{w}}\right)}+\frac{(\alpha \tau)_{\mathrm{eff}} G_{\mathrm{c}}+U_{\mathrm{t}} T_{\mathrm{a}}}{U_{\mathrm{t}}+U_{\mathrm{T}}}
$$

where the terms $U$ are some of the overall heat transfer coefficients. Their details are given by Tiwari and Sodha [23].

In our problem, the net input energy rate included solar radiation intensity received by the cascade solar still and PV/T collector.

$$
E n_{\text {in,net }}=E n_{\text {solar }, \mathrm{s}}+E n_{\text {solar, } \mathrm{c}}=A_{\mathrm{p}} G_{\mathrm{s}}+A_{\mathrm{c}} G_{\mathrm{c}}
$$

The energy efficiency of stepped cascade solar still connected to PV/T collector was obtained by substituting Eqs. (7) to (12) into Eq. (6) as follows

$$
\eta_{\mathrm{en}}=\frac{E n_{\text {out,des }}}{E n_{\mathrm{in}, \mathrm{net}}}=\frac{h_{\mathrm{ev}, \mathrm{w}-\mathrm{g}} A_{\mathrm{w}}\left(T_{\mathrm{w}}-T_{\mathrm{g}}\right)}{A_{\mathrm{p}} G_{\mathrm{s}}+A_{\mathrm{c}} G_{\mathrm{c}}}+\frac{A_{\mathrm{c}} G_{\mathrm{c}} \eta_{\mathrm{el}, \mathrm{ref}}\left[1-0.0045\left(T_{\mathrm{c}}-T_{\mathrm{a}, \mathrm{ref}}\right)\right]-\frac{\dot{m}_{\mathrm{w}} \Delta P}{\rho_{\mathrm{w}} \eta_{\mathrm{pump}}}}{C_{\mathrm{f}}\left(A_{\mathrm{p}} G_{\mathrm{s}}+A_{\mathrm{c}} G_{\mathrm{c}}\right)}
$$

The quality of thermal energy and electrical energy were not the same. Here, $C_{\mathrm{f}}$ is a conversion factor which converts the electrical power output of PV/T collector to its equivalent thermal power [23].

\section{Validation}

Equations (1), (2) and (5) constitute a set of nonlinear ordinary differential equations for unknown temperatures $T_{\mathrm{g}}, T_{\mathrm{w}}$ and $T_{\mathrm{p}}$. This set was solved by 4th-order Runge-Kutta 
method, numerically. It was necessary to validate the numerical model of the present research with respect to experimental data. Since there was no experimental data for the stepped cascade solar still connected to PV/T collector, the validation was carried out in two steps. First, the validation of the simulation results of the stepped cascade solar still was carried out with the experimental data of Farshchi Tabrizi et al. [7]. Then, the results of numerical simulation of $\mathrm{PV} / \mathrm{T}$ collector were validated by the experimental data of Yazdanpanahi et al. [11]. The design parameters of cascade solar still and PV/T collector are given in Table 1.

In order to compare the simulation results with the experimental data, an average relative error has been evaluated by the following equation:

$$
E r=\frac{1}{n} \sum_{\mathrm{i}=1}^{n}\left|\frac{X_{\text {sim }, \mathrm{i}}-X_{\text {exp } \mathrm{i}}}{X_{\text {exp, }}}\right| \times 100
$$

where $\mathrm{n}$ is the number of the experiments carried out.

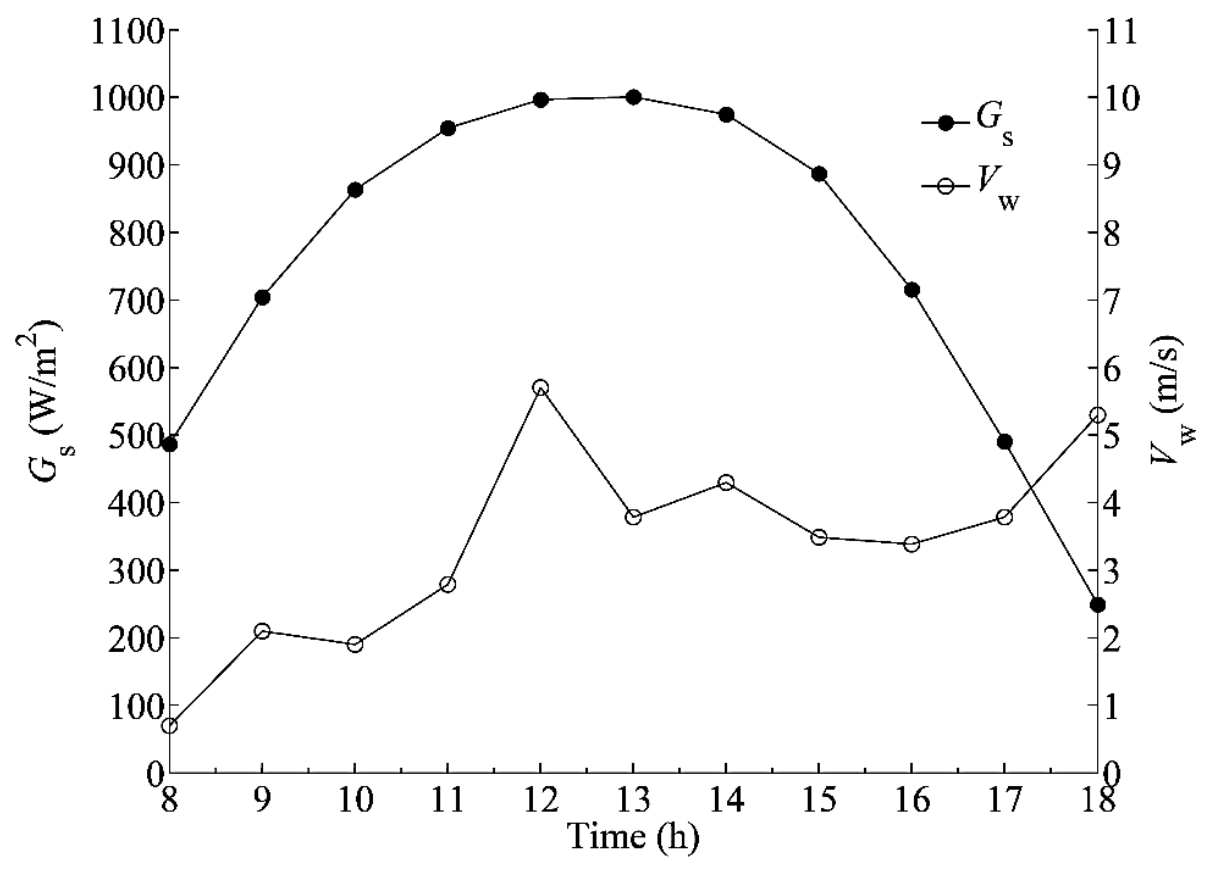

Figure 3. Variations of solar radiation intensity on cascade solar still and wind velocity during the test day.

\section{Validation of Cascade Solar Still}

Farshchi Tabrizi et al. [7] have studied the influence of water flow rate on the internal heat and mass transfer and daily productivity of a cascade solar still, experimentally. They proposed a modified correlation for evaporative heat transfer coefficient in cascade solar still. Their experimental setup included a weir-type cascade solar still with 15 matte black paint steps and a feed storage tank. The storage tank was placed about $1.5 \mathrm{~m}$ above the still to supply a constant mass flow rate of brackish water into the solar still. Their experiments were carried out between 8 a.m. and 6 p.m. local time (28/06/2009) at University of Sistan and Baluchestan, Zahedan, Iran. Their experimental data included 
solar radiation intensity, wind velocity, ambient temperature, glass cover temperature, brackish water temperature and freshwater productivity. The variations of solar radiation intensity on solar still and wind velocity during the test day are shown in Figure 3. It can be seen that Figure 3 shows that the solar radiation intensity increased with time and achieved its maximum value at 1 p.m. and then its value decreased with time. The maximum value of solar radiation intensity is about $1000 \mathrm{~W} / \mathrm{m}^{2}$, which is greater than the daily average value of $756.2 \mathrm{~W} / \mathrm{m}^{2}$. Figure 3 also shows that the test day was a windy day. The daily average value of wind velocity is $3.38 \mathrm{~m} / \mathrm{s}$. The various temperatures of cascade solar still (absorber plate temperature, brackish water temperature, glass cover temperature and ambient temperature) during the test day are shown in Figure 4.

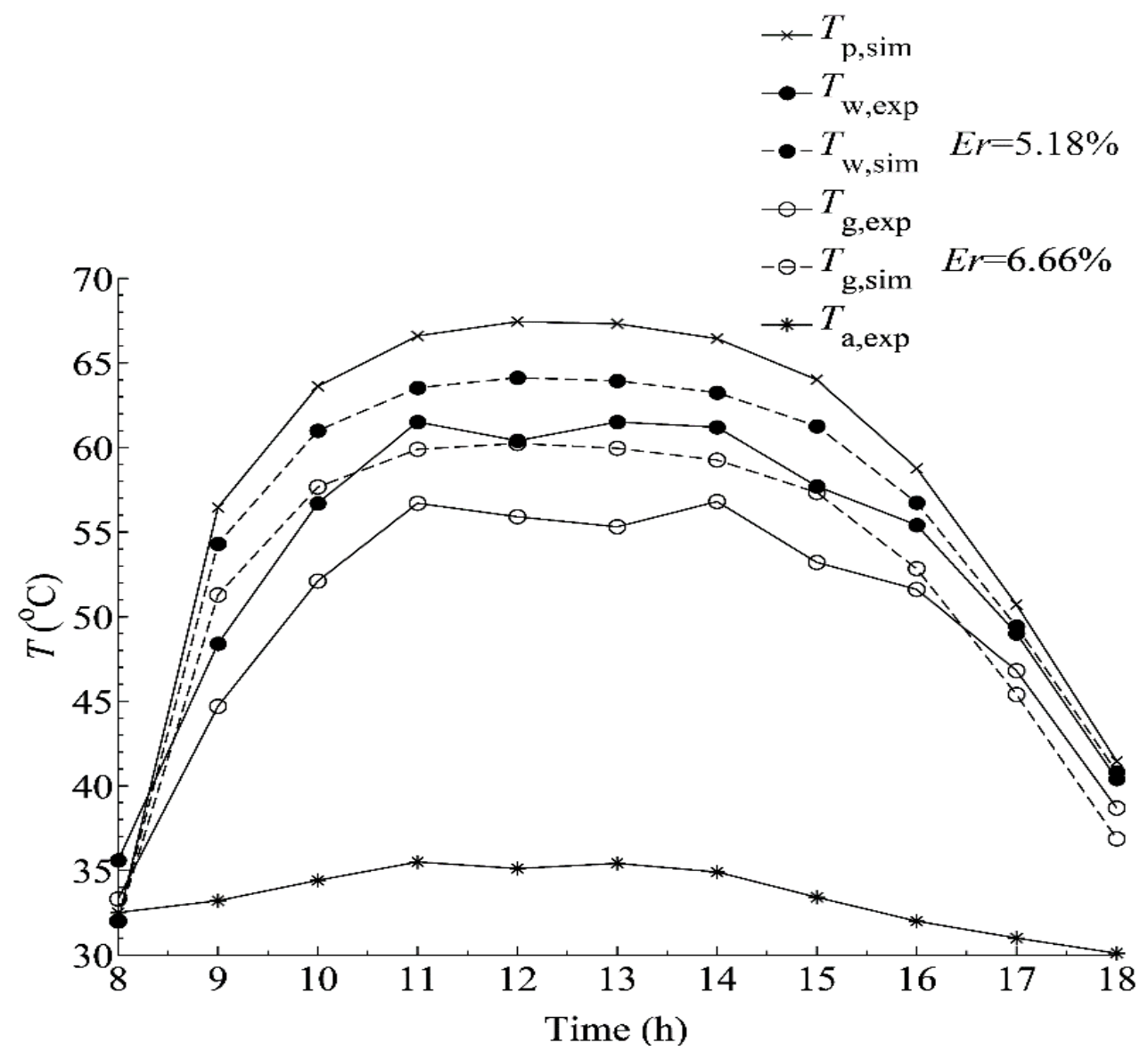

Figure 4. Various temperatures of cascade solar still during the test day.

In Figure 4, the simulated values of brackish water temperature and glass cover temperature were validated with the corresponding experimental temperatures. The relative errors of these temperatures were $5.18 \%$ and $6.66 \%$, respectively. Also, the average value of ambient temperature for the test day was $33.4^{\circ} \mathrm{C}$. Unfortunately, the experimental values of absorber plate temperature were not given by Farshchi Tabrizi et al. [7]. Therefore, its simulated values were only reported. The simulated and experimental values of freshwater productivity during the test day are shown in Figure 5. According to Figure 5, it was observed that there was a fair agreement between the simulated and experimental value of this parameter with a relative error of $15.16 \%$. When the variations range of a parameter was very low, the relative error was not suitable 
criterion for the comparison process. Therefore, the linear coefficient of regression was evaluated.

$$
R=\frac{n\left(\sum_{\mathrm{i}=1}^{n} X_{\text {exp, }} \cdot X_{\text {sim }, \mathrm{i}}\right)-\left(\sum_{\mathrm{i}=1}^{n} X_{\text {exp,i }}\right) \cdot\left(\sum_{\mathrm{i}=1}^{n} X_{\text {sim }, \mathrm{i}}\right)}{\sqrt{n\left(\sum_{\mathrm{i}=1}^{n} X_{\text {exp }, \mathrm{i}}^{2}\right)-\left(\sum_{\mathrm{i}=1}^{n} X_{\text {exp }, \mathrm{i}}\right)^{2}} \cdot \sqrt{n\left(\sum_{\mathrm{i}=1}^{n} X_{\text {sim }, \mathrm{i}}^{2}\right)-\left(\sum_{\mathrm{i}=1}^{n} X_{\text {sim }, \mathrm{i}}\right)^{2}}}
$$

The value of ' $R$ ' closer to 1 is preferred. According to Figure 6, the linear coefficient of regression between the simulated and experimental values of freshwater productivity is 0.94 .

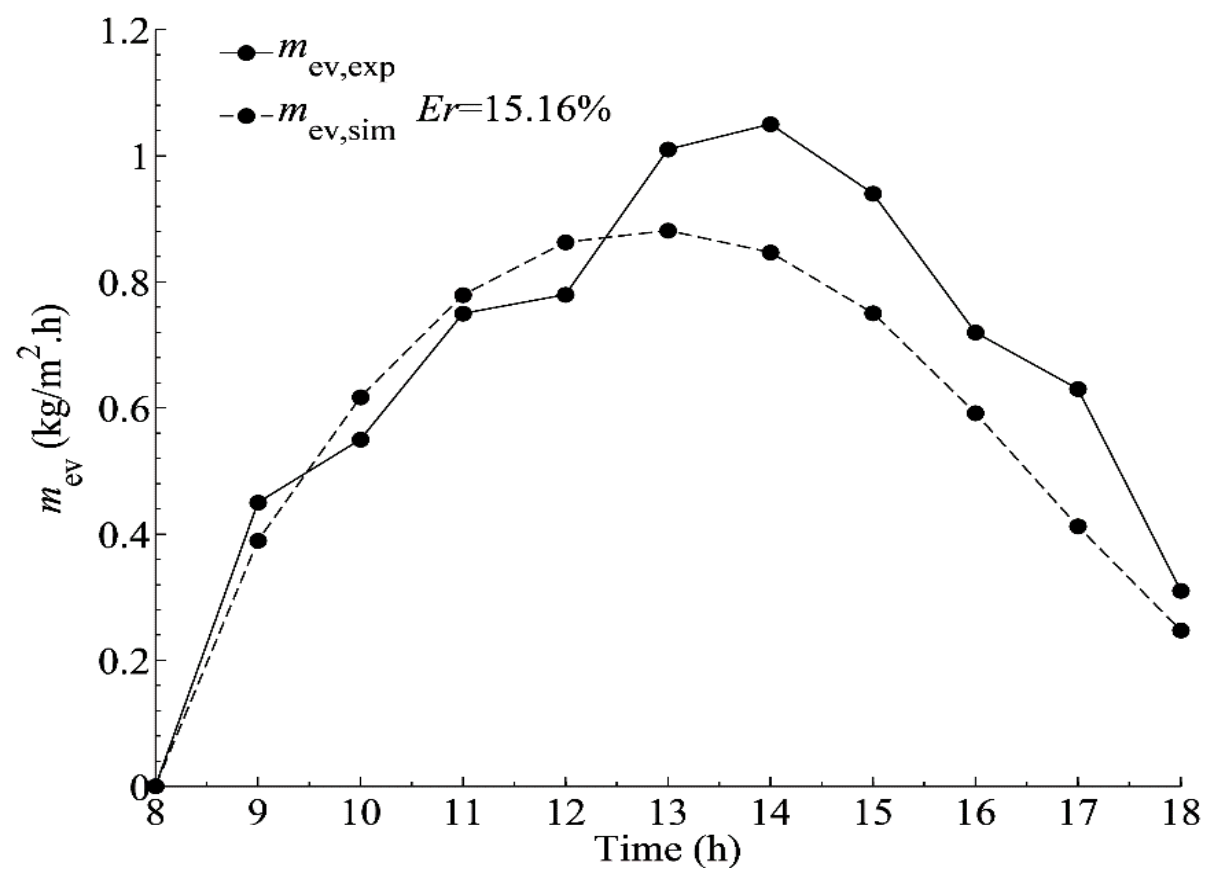

Figure 5. Simulated and experimental values of freshwater productivity during the test day.

\section{Validation of $P V / T$ collector}

Yazdanpanahi et al. [11] have investigated the exergy efficiency of a water PV/T collector, experimentally. They have proposed a modified equation for the energy efficiency of PV/T collector which was based on exergy losses. Their experimental setup consisted of one mono-crystalline silicon PV module (90W) integrated with a solar water collector. Their measurements were carried out during a clear day (November 2012) from 8:00 a.m. to 4:00 p.m. local time at University of Sistan and Baluchestan, Zahedan, Iran. Their measured data included solar radiation intensity, ambient temperature, average water temperature, PV/T collector temperature and electrical power output. Figure 7 shows the variations of solar radiation intensity on PV/T collector during the test day. 


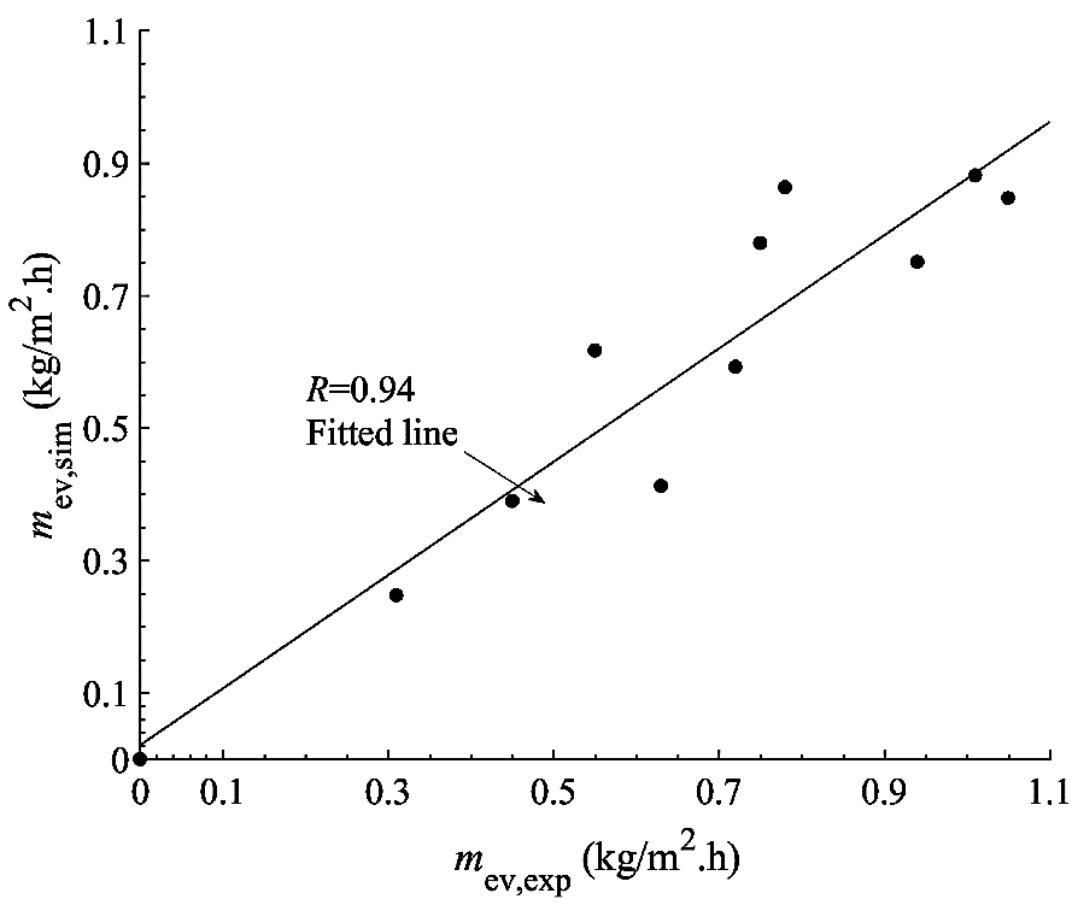

Figure 6. Simulated values of freshwater productivity in terms of its experimental values for the test day.

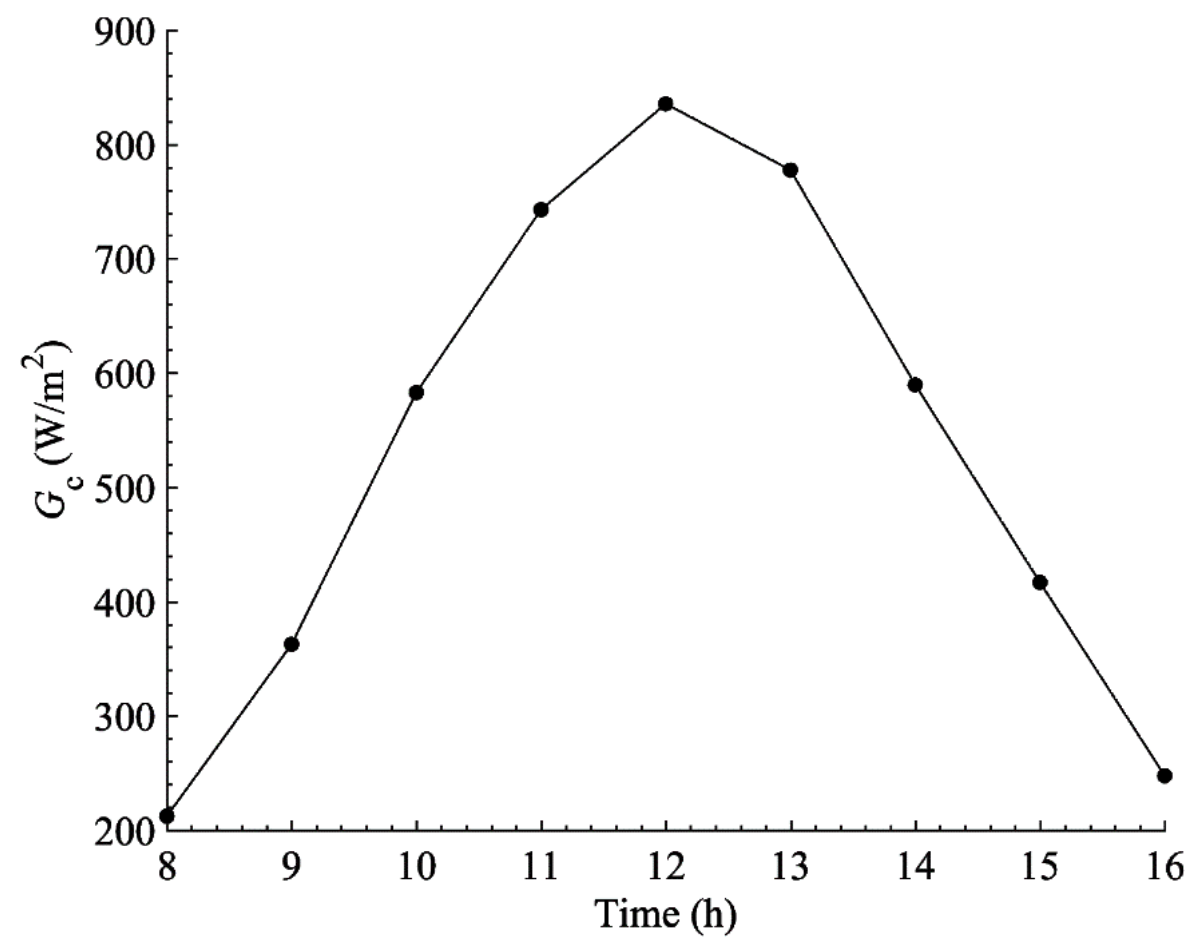

Figure 7. Variations of solar radiation intensity on PV/T collector during the test day.

According to Figure 7, the maximum value of solar radiation intensity occurred at noon. The various temperatures of $\mathrm{PV} / \mathrm{T}$ collector $(\mathrm{PV} / \mathrm{T}$ collector temperature, average water temperature and ambient temperature) during the test day are shown in Figure 8. 


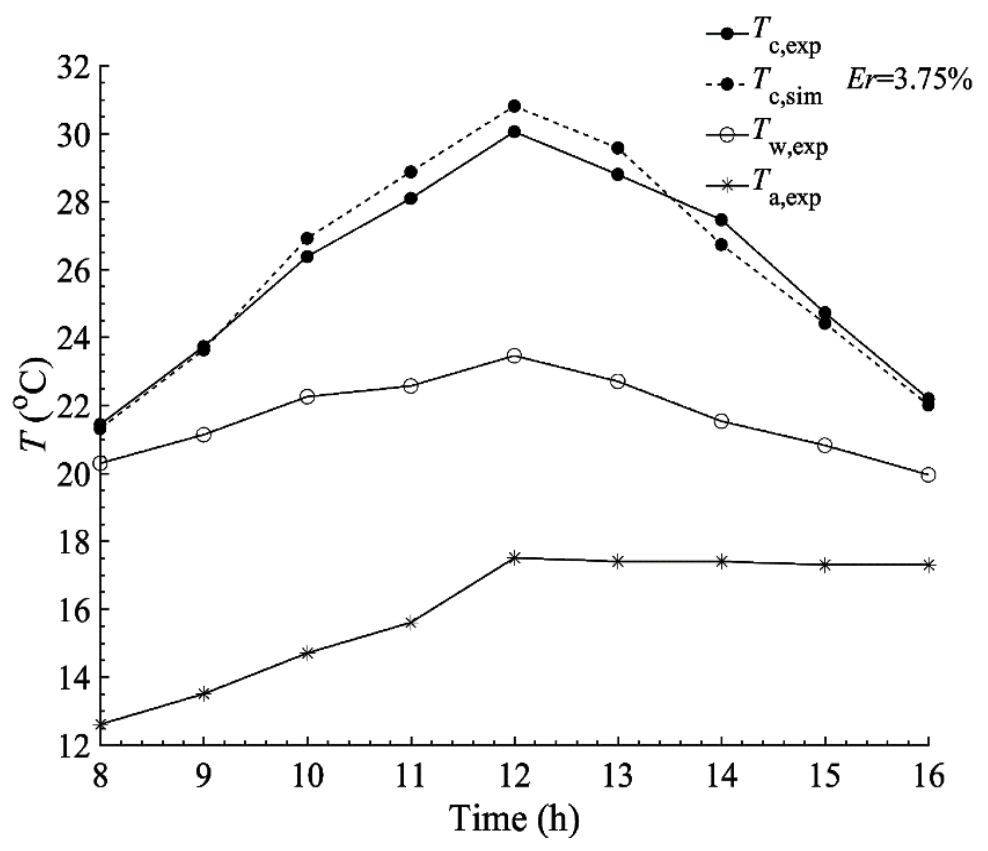

Figure 8. Various temperatures of PV/T collector during the test day

The simulated values of $\mathrm{PV} / \mathrm{T}$ collector temperature were validated with the experimental values related to Yazdanpanahi et al. [11]. Its relative error is $3.75 \%$. In Figure 9, the experimental and simulated values of the output of electrical power of PV/T collector are shown.

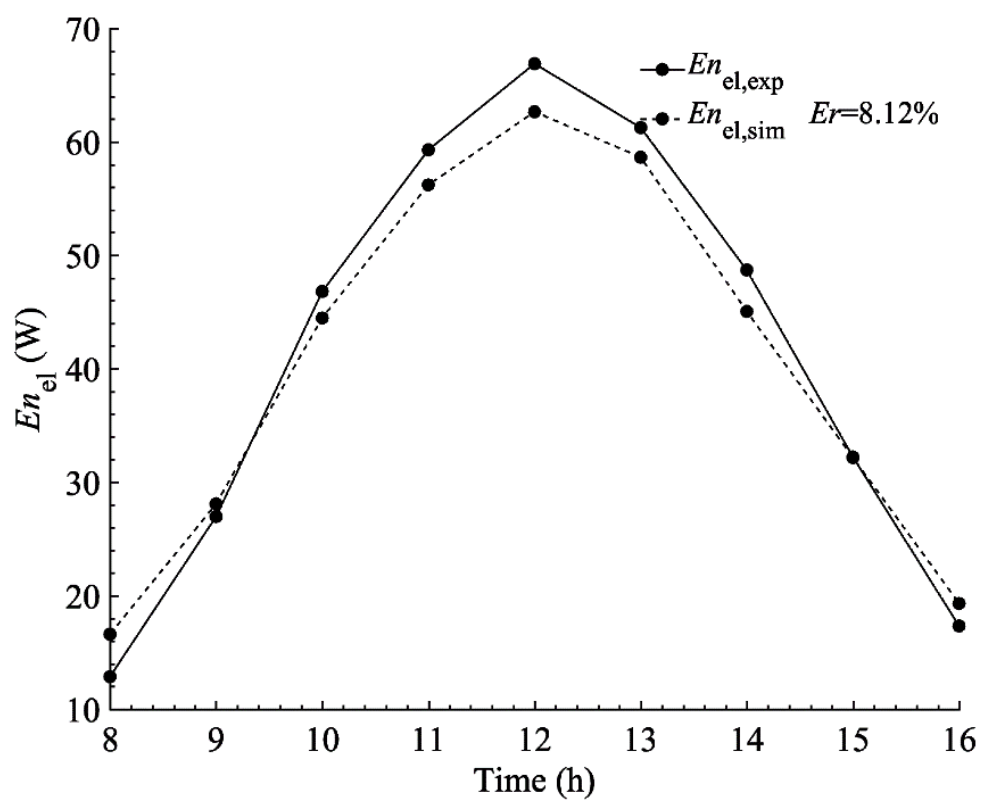

Figure 9. Simulated and experimental values of electrical power output of PV/T collector during the test day.

According to Figure 9, a comparison between the experimental and simulated values of electrical power output of PV/T collector was carried out. Its relative error is $8.12 \%$. It is observed from Figures 4 to 9 that there is a good agreement between the simulation 
results of the present study and the experimental data of Farshchi Tabrizi et al. [7] and Yazdanpanahi et al. [11].

\section{RESULTS AND DISCUSSION}

In this section, parametric studies were carried out and the effect of various operating and design parameters on the energy efficiency, freshwater productivity and electrical power output was investigated. Figure 10 shows the variations of the energy efficiency versus the area of PV/T collector for the different values of the mass flow rate of brackish water. In order to plot Figure 10, the daily average value of solar radiation intensity, ambient temperature and wind velocity of Farshchi Tabrizi et al. [7] were used which are reported above in the figure.

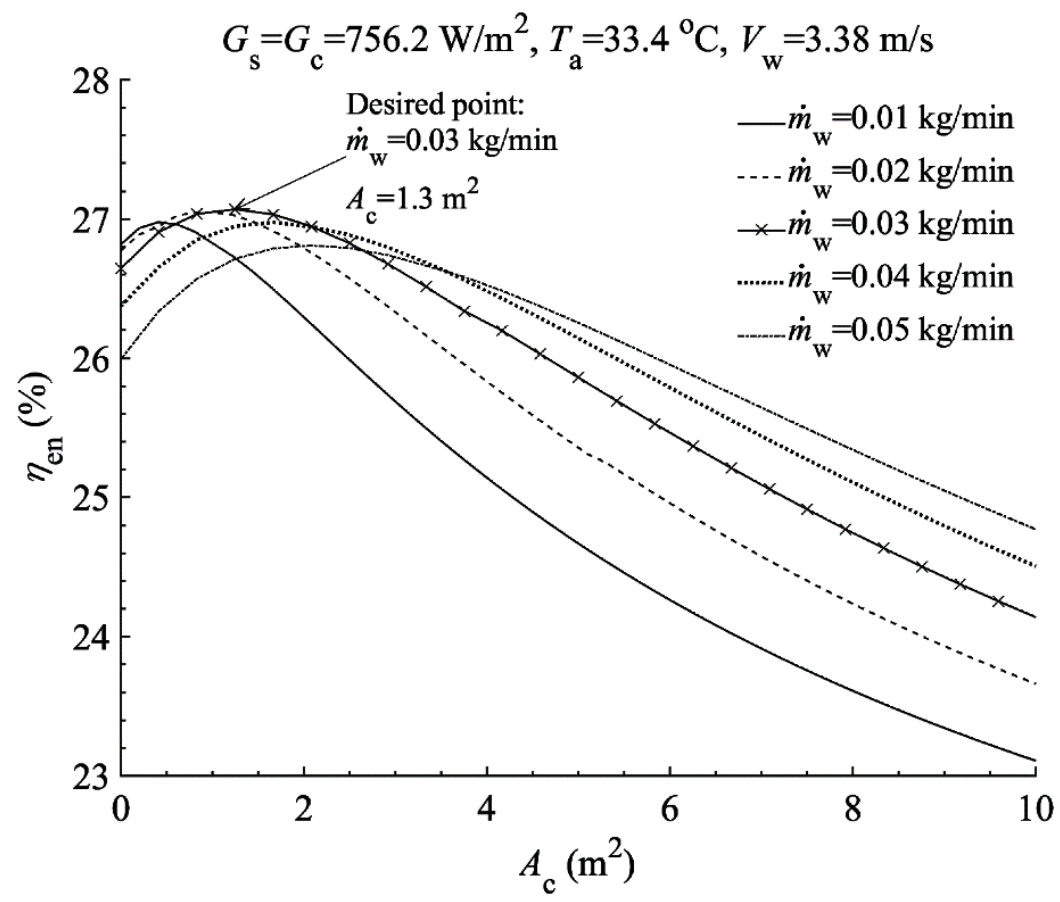

Figure 10. Variations of the energy efficiency versus the area of PV/T collector for the different values of the mass flow rate of brackish water.

According to Figure 10, it was observed that there was a desired point for the mass flow rate of brackish water and the PV/T collector area which maximised the energy efficiency. The desired value of the mass flow rate of brackish water and the PV/T collector area is $0.03 \mathrm{~kg} / \mathrm{min}$ and $1.3 \mathrm{~m}^{2}$, respectively. The area of $1.3 \mathrm{~m}^{2}$ is equivalent to about two PV/T collectors of Yazdanpanahi et al. [11]. The larger PV/T collector area after the desired point caused the long piping system in PV/T collector. Therefore, the pressure drop and pumping power increases. According to Eq. (10), the pumping power is subtracted from electrical power output of PV/T collector. Also, the consumed electrical power of pump is a negative term in the numerator of Eq. (13). Therefore, the high value of pumping power after the desired point decreased the energy efficiency. Yazdanpanahi et al. [11] have shown that the pumping power is an incremental function of PV/T collector area. On the other hand, the increase of the mass flow rate of brackish water after the desired point increased the Reynolds number of the brackish water flow and the water layer thickness on steps. The increase of the Reynolds number increased 
the pressure drop and pumping power, while the increase of water layer thickness decreased the evaporation rate. The simultaneous effect of these factors reduced the efficiency. The next figures investigate the daily behaviour of the energy efficiency, freshwater productivity and electrical power output. It should be mentioned that the climatic conditions of Farshchi Tabrizi et al. [7] were used to plot the next figures.

The variations of energy efficiency with time are shown in Figure 11.

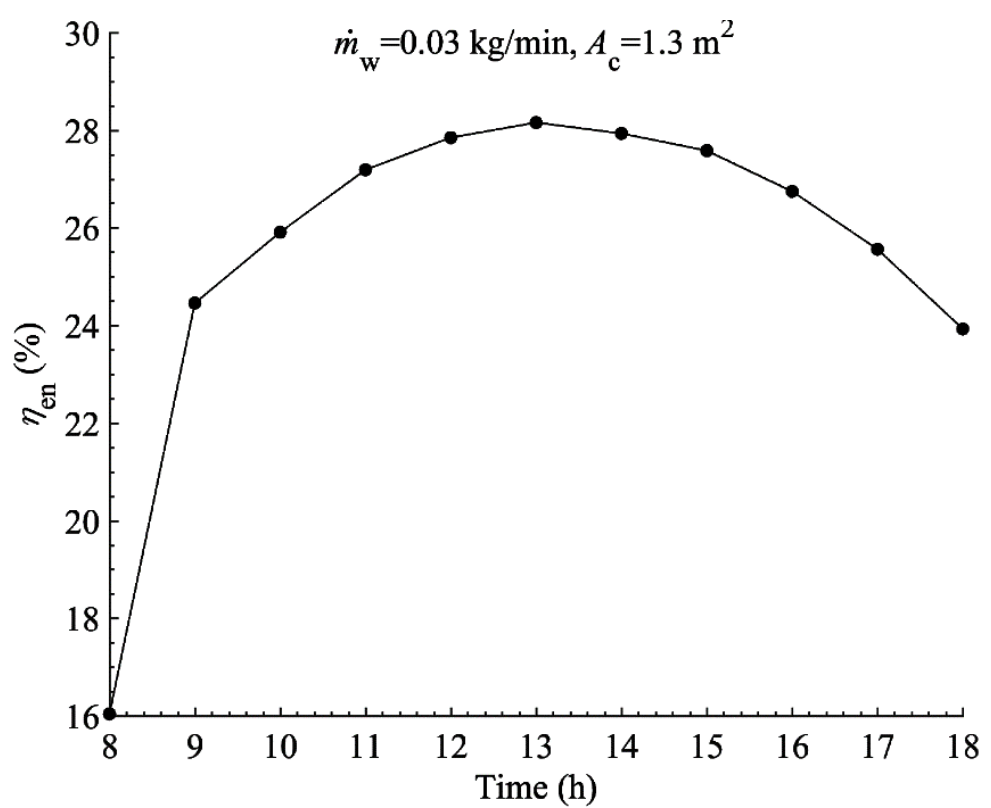

Figure 11. Variations of energy efficiency with time

It was observed from Figure 11 that the energy efficiency increased with time until it reached a maximum value at about 13 p.m. and then reduced till sunset. The variations of energy efficiency with time corresponded with the variations of solar radiation intensity during the day. The daily energy efficiency is about $26 \%$. Figure 12 shows the daily freshwater productivity for the various mass flow rate of brackish water. It was observed from Figure 12 that daily freshwater productivity increased with the increase of mass flow rate of brackish water. According to Eqs. (3) and (4), the increase of mass flow rate of brackish water caused the increase of heat removal factor $\left(F_{R}\right)$ and the useful heat gain of PV/T collector $\left(Q_{\mathrm{c}}\right)$. Therefore, the brackish water temperature and the evaporation rate increased. As a result, the daily freshwater productivity increased. However, this increase was noticeable at noontime. The energy input to the solar still system was only provided for solar radiation intensity. At noon, due to the high potential of solar radiation intensity, the freshwater productivity was high.

In Figure 13, the daily freshwater productivity was plotted for the different values of PV/T collector area. In this figure, a comparison between cascade solar still with and without PV/T collector was carried out. According to the figure, the connection of PV/T collector to cascade solar still can improve freshwater productivity to about $20 \%$. The accumulated freshwater is about $5.71 \mathrm{~kg} /\left(\mathrm{m}^{2}\right.$.day $)$. However, the increase of daily freshwater productivity was negligible after the desired value of PV/T collector area. According to Eq. (3), the increase of PV/T collector area caused the increase of heat loss rate from PV/T collector. In other word, PV/T heat gain had a constant value. Therefore, after the desired value of PV/T collector area, the constant PV/T heat gain cannot increase 
the brackish water temperature. Therefore, the daily freshwater productivity did not change.

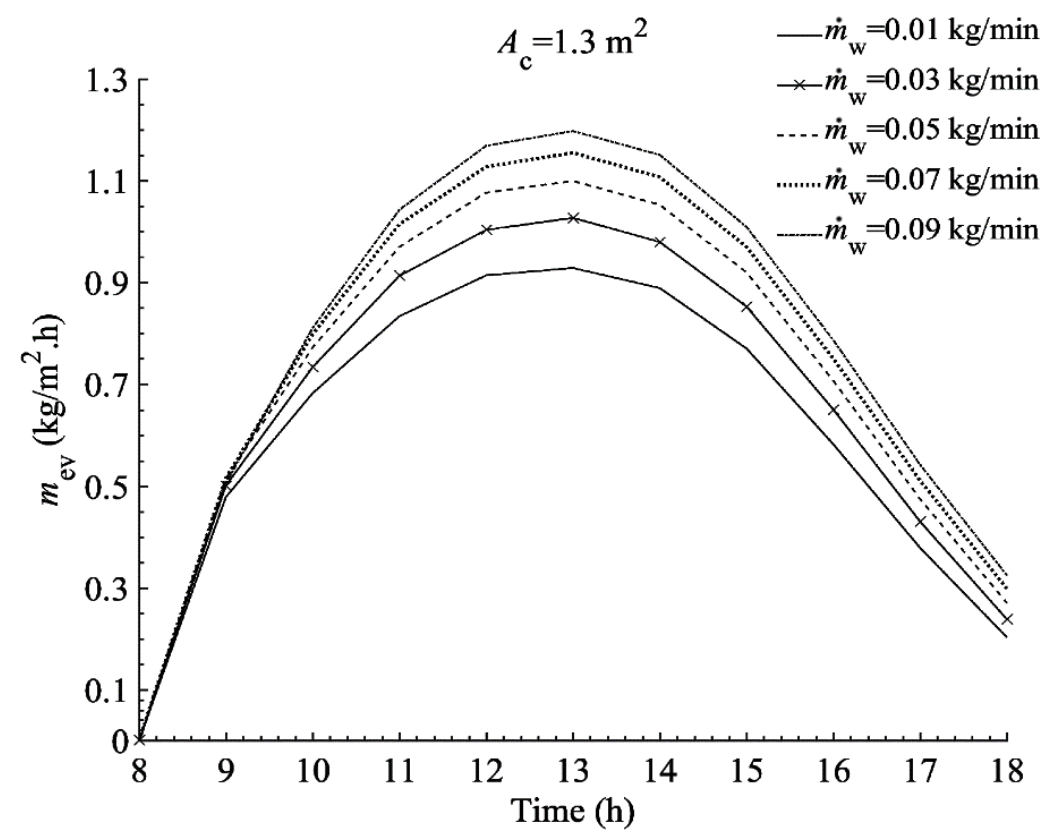

Figure 12. Daily freshwater productivity for the various mass flow rate of brackish water.

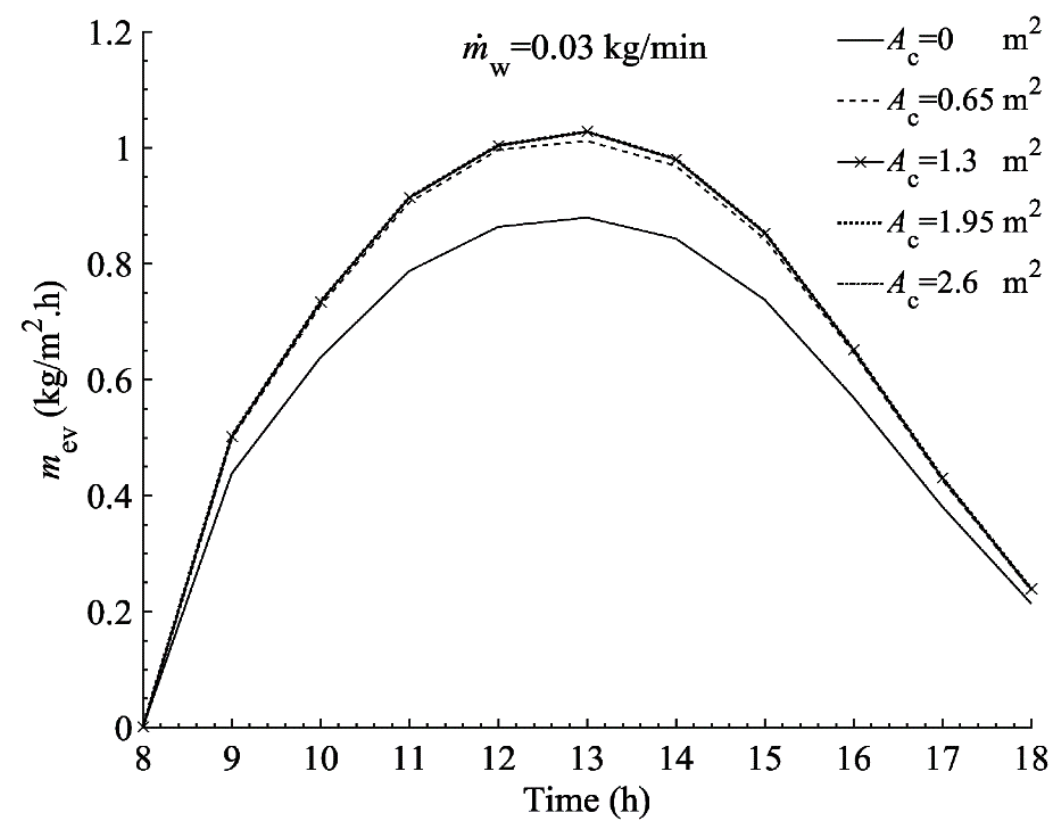

Figure 13. Daily freshwater productivity for the different values of area of PV/T collector.

The daily electrical power output for the different mass flow rate of brackish water is shown in Figure 14. It was observed from Figure 14 that by increasing the mass flow rate of brackish water, the daily electrical power output decreased. According to Eqs. (3) and (4), the increase of mass flow rate of brackish water caused the increase of heat removal 
factor and the useful heat gain of PV/T collector. Therefore, the brackish water temperature increased. According to Eq. (11), by increasing brackish water temperature, the PV/T collector temperature increased. As a result, daily electrical power output reduced. On the other hand, the increase of mass flow rate of brackish water caused the increase of pumping power and reduced the daily electrical power output.

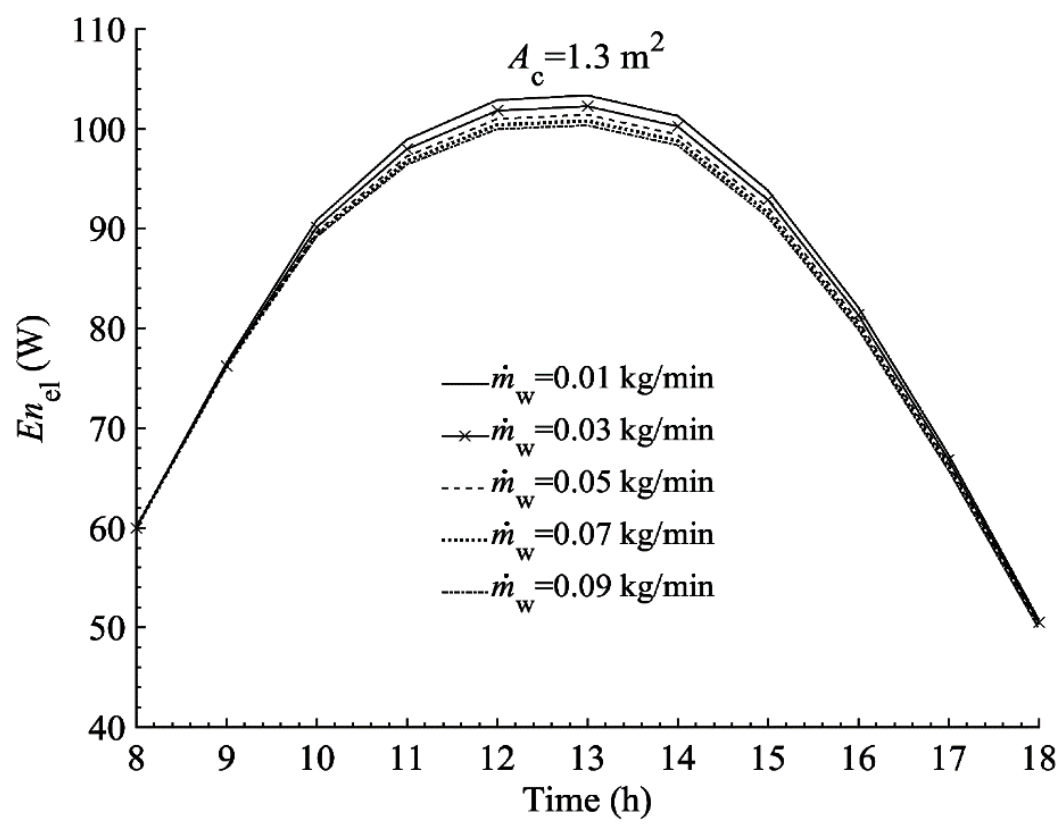

Figure 14. Daily electrical power output for the different mass flow rate of brackish water

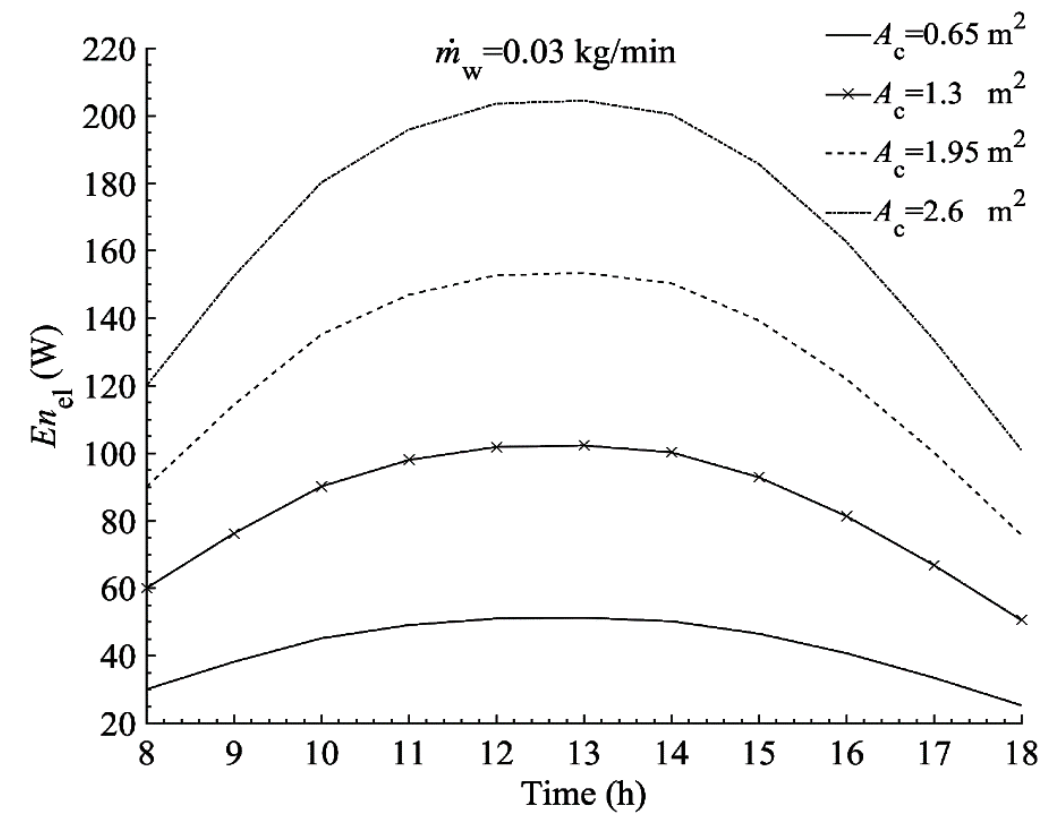

Figure 15. Daily electrical power output for the different values of PV/T collector area.

Figure 15 shows the daily electrical power output for the different values of PV/T collector area. It is clear from Figure 15 that by increasing the PV/T collector area, the number of PV cells in PV/T collector increased. Therefore, daily electrical power output 
increased. A PV/T collector with an area of $1.3 \mathrm{~m}^{2}$ in addition to providing pumping power can give the electrical power of about $0.918 \mathrm{~kW} /$ day for other uses.

\section{CONCLUSIONS}

The important findings of the present study can be summarised as follows:

- the maximum energy efficiency of stepped cascade solar still was obtained in the desired brackish water flow of $0.03 \mathrm{~kg} / \mathrm{min}$ and the PV/T collector area of $1.3 \mathrm{~m}^{2}$;

- the connection of PV/T collector to cascade solar still improved freshwater productivity by $20 \%$;

- $\mathrm{PV} / \mathrm{T}$ collector in addition to providing pumping power gave the electrical power of about $0.918 \mathrm{~kW} /$ day for other uses.

- the daily energy efficiency of stepped cascade solar still connected to PV/T collector is about $26 \%$.

The performance of stepped cascade solar still was limited to sunny hours. For further study, the addition of the phase change materials below the absorber plate in order to produce freshwater during the night time is suggested.

\section{ACKNOWLEDGEMENTS}

The authors would like to acknowledge the financial support of University of Sistan and Baluchestan for this research under grant number 9401.

\section{REFERENCES}

[1] Velmurugan V, Gopalakrishnan M, Raghu R, Srithar K. Single basin solar still with fin for enhancing productivity. Energy Conversion and Management. 2008;49:2602-8.

[2] Abidin C, Ong S, Makhtar SM, Rahmat N, Ahmad R. Decolourization and cod reduction of textile wastewater by ozonation in combination with biological treatment. International Journal of Automotive and Mechanical Engineering. 2016;13:3141.

[3] Alias A, Kinoshita H, Nishina Y, Fujii M. Dependence of pH level on tribological effect of graphene oxide as an additive in water lubrication. International Journal of Automotive and Mechanical Engineering. 2016;13:3150.

[4] Azaini N, Masngut N. Oscillatory flow reactor design for biological process.

[5] Tahseen TA, Ishak M, Rahman M. Laminar forced convection heat transfer over staggered circular tube banks: A CFD approach. Journal of Mechanical Engineering and Sciences. 2013;4:418-30.

[6] Ehsan MM, Salehin M, Islam A. Investigation of thermal and hydrodynamic behaviour of Al2O3-water nanofluid through a rough parallel plate.

[7] Tabrizi FF, Dashtban M, Moghaddam H, Razzaghi K. Effect of water flow rate on internal heat and mass transfer and daily productivity of a weir-type cascade solar still. Desalination. 2010;260:239-47.

[8] Sadineni SB, Hurt R, Halford CK, Boehm RF. Theory and experimental investigation of a weir-type inclined solar still. Energy. 2008;33:71-80.

[9] Montazeri M, Banakar A, Ghobadian B. Design and evaluation of a new absorber plate for cascade solar still. Technical Journal of Engineering and Applied Sciences Available online at www tjeas com. 2013:1666-75. 
[10] Kumar S, Tiwari A. Design, fabrication and performance of a hybrid photovoltaic/thermal (PV/T) active solar still. Energy Conversion and Management. 2010;51:1219-29.

[11] Yazdanpanahi J, Sarhaddi F, Adeli MM. Experimental investigation of exergy efficiency of a solar photovoltaic thermal (PVT) water collector based on exergy losses. Solar Energy. 2015;118:197-208.

[12] Headley OSC. Cascade solar still for distilled water production. Solar Energy. 1973;15:245-58.

[13] Dashtban M, Tabrizi FF. Thermal analysis of a weir-type cascade solar still integrated with PCM storage. Desalination. 2011;279:415-22.

[14] Alaudeen A, Johnson K, Ganasundar P, Abuthahir AS, Srithar K. Study on stepped type basin in a solar still. Journal of King Saud University-Engineering Sciences. 2014;26:176-83.

[15] Hansen RS, Narayanan CS, Murugavel KK. Performance analysis on inclined solar still with different new wick materials and wire mesh. Desalination. 2015;358:1-8.

[16] El-Samadony Y, El-Maghlany WM, Kabeel A. Influence of glass cover inclination angle on radiation heat transfer rate within stepped solar still. Desalination. 2016;384:68-77.

[17] Sathyamurthy R, Samuel DH, Nagarajan P. Theoretical analysis of inclined solar still with baffle plates for improving the fresh water yield. Process Safety and Environmental Protection. 2016;101:93-107.

[18] Bhalara B, Varshney R, Yadav AK. Experimental Analysis of Modified Stepped Solar Still.

[19] Saettone E, Valencia-Tovar Y, Gómez-de-la-Torre-Gastello A. Preliminary overview and evaluation of a stepped solar distiller with internal reflective walls and borosilicate vacuum tubes. Desalination. 2017;413:136-43.

[20] Nagarajan P, El-Agouz S, DG HS, Edwin M, Madhu B, Sathyamurthy R, et al. Analysis of an inclined solar still with baffles for improving the yield of fresh water. Process Safety and Environmental Protection. 2017;105:326-37.

[21] Abujazar MSS, Fatihah S, Lotfy E, Kabeel A, Sharil S. Performance evaluation of inclined copper-stepped solar still in a wet tropical climate. Desalination. 2018;425:94-103.

[22] Rashidi S, Bovand M, Rahbar N, Esfahani JA. Steps optimization and productivity enhancement in a nanofluid cascade solar still. Renewable Energy. 2018;118:53645.

[23] Tiwari A, Sodha M. Performance evaluation of solar PV/T system: an experimental validation. Solar Energy. 2006;80:751-9.

$\begin{array}{ll}A & \left(\mathrm{~m}^{2}\right) \\ C & \left(\mathrm{~J} / \mathrm{kg} .{ }^{\circ} \mathrm{C}\right) \\ C_{\mathrm{f}} & \\ d & (\mathrm{~m}) \\ E r & (\%) \\ E n & (\mathrm{~W}) \\ F_{R} & \end{array}$

\section{NOMENCLATURES}

area

specific heat capacity

energy conversion factor

distance between glass cover and water surface

relative error

energy rate

heat removal factor 


\begin{tabular}{|c|c|c|}
\hline$F^{\prime}$ & & fin efficiency factor \\
\hline$g$ & $\left(\mathrm{~m} / \mathrm{s}^{2}\right)$ & gravity acceleration \\
\hline$G$ & $(\mathrm{~W} / \mathrm{m})$ & solar radiation intensity \\
\hline$G r^{\prime}$ & & modified Grashof number \\
\hline$h$ & $\left(\mathrm{~W} / \mathrm{m}^{2} . \mathrm{K}\right)$ & overall heat transfer \\
\hline$h_{\mathrm{fg}}$ & $(\mathrm{J} / \mathrm{kg})$ & latent heat of water \\
\hline$h_{p 1}$ & & $\begin{array}{l}\text { penalty factor due to the presence of solar cell material, glass } \\
\text { and EVA }\end{array}$ \\
\hline$h_{p 2}$ & & penalty factor due to the presence of interface between absorber \\
\hline$k$ & $\left(\mathrm{~W} / \mathrm{m} \cdot{ }^{\circ} \mathrm{C}\right)$ & $\begin{array}{l}\text { plate and working fluid } \\
\text { thermal conductivity }\end{array}$ \\
\hline$m$ & $(\mathrm{~kg})$ & mass \\
\hline$m_{\mathrm{ev}}$ & $\left(\mathrm{kg} / \mathrm{m}^{2} . \mathrm{h}\right)$ & mass of distillated \\
\hline$\dot{m}$ & $(\mathrm{~kg} / \mathrm{s})$ & mass flow rate of water \\
\hline$n$ & & number of the experiment carried out \\
\hline$Q$ & $(\mathrm{~W})$ & useful heat gain of PV/T collector \\
\hline$P$ & $(\mathrm{~Pa})$ & pressure \\
\hline $\operatorname{Pr}$ & & Prandtl number \\
\hline$R$ & & linear coefficient of regression \\
\hline$t$ & (s) & time \\
\hline$T$ & $\left({ }^{\circ} \mathrm{C}\right)$ & temperature \\
\hline$T^{\prime}$ & $\left({ }^{\circ} \mathrm{C}\right)$ & temperature \\
\hline$T_{\mathrm{i}}$ & $\left({ }^{\circ} \mathrm{C}\right)$ & average temperature \\
\hline$U$ & $\left(\mathrm{~W} / \mathrm{m}^{2} . \mathrm{K}\right)$ & overall heat loss coefficient \\
\hline$V$ & $(\mathrm{~m} / \mathrm{s})$ & wind speed \\
\hline$X$ & & experimental or simulated parameter \\
\hline \multicolumn{3}{|c|}{ Greek symbols } \\
\hline$\alpha$ & & absorptivity \\
\hline$(\alpha \tau)_{\mathrm{eff}}$ & & product of effective absorptivity and transmissivity \\
\hline$\beta$ & $(1 / \mathrm{K})$ & thermal expansion coefficient \\
\hline$\Delta$ & & difference in pressure, temperature, time \\
\hline$\varepsilon$ & & emissivity \\
\hline$\eta$ & $(\%)$ & efficiency \\
\hline$\rho$ & $\left(\mathrm{kg} / \mathrm{m}^{3}\right)$ & density \\
\hline$\sigma$ & $\left(\mathrm{W} / \mathrm{m}^{2} \cdot \mathrm{K}^{4}\right)$ & Stefan-Boltzmann's constant \\
\hline$\mu$ & $\left(\mathrm{N} . \mathrm{s} / \mathrm{m}^{2}\right)$ & viscosity \\
\hline$\tau$ & & transmissivity \\
\hline \multicolumn{3}{|c|}{ Subscripts } \\
\hline $\mathrm{a}$ & & ambient \\
\hline c & & collector, convective \\
\hline des & & desired \\
\hline eff & & effective \\
\hline el & & electrical \\
\hline en & & energy \\
\hline ev & & evaporative \\
\hline $\exp$ & & experimental \\
\hline g & & glass cover \\
\hline $\mathrm{i}$ & & i-th parameter \\
\hline in & & inlet \\
\hline
\end{tabular}




$\begin{array}{ll}\text { loss } & \text { loss } \\ \text { net } & \text { net } \\ \text { out } & \text { outlet } \\ \mathrm{p} & \text { absorber plate } \\ \text { pump } & \text { pump } \\ \mathrm{r} & \text { radiative } \\ \text { ref } & \text { reference } \\ \mathrm{t} & \text { top } \\ \mathrm{T} & \text { tedlar } \\ \mathrm{tT} & \text { tedlar to top } \\ \mathrm{s} & \text { still } \\ \text { sim } & \text { Simulated } \\ \text { sky } & \text { Sky } \\ \text { solar } & \text { Solar } \\ \mathrm{V} & \text { humid air }\end{array}$

\section{APPENDIX}

The related heat transfer coefficients are defined as follows [7, 13, 17]

$$
\begin{aligned}
& h_{\mathrm{c}, \mathrm{g}-\mathrm{a}}=2.8+3 V_{\mathrm{w}} \text { for } V_{\mathrm{w}} \leq 5 \\
& h_{\mathrm{c}, \mathrm{g}-\mathrm{a}}=5.7+2.8 V_{\mathrm{w}} \text { for } V_{\mathrm{w}}>5 \\
& h_{\mathrm{r}, \mathrm{g}-\mathrm{sky}}=\varepsilon_{\mathrm{g}} \sigma\left[\frac{\left(T_{\mathrm{g}}+273\right)^{4}-\left(T_{\text {sky }}+273\right)^{4}}{T_{\mathrm{g}}-T_{\text {sky }}}\right] \\
& T_{\text {sky }}=T_{\mathrm{a}}-6 \\
& h_{\mathrm{w}-\mathrm{g}}=h_{\mathrm{r}, \mathrm{w}-\mathrm{g}}+h_{\mathrm{ev}, \mathrm{w}-\mathrm{g}}+h_{\mathrm{c}, \mathrm{w}-\mathrm{g}} \\
& h_{\mathrm{r}, \mathrm{w}-\mathrm{g}}=\varepsilon_{\mathrm{eff}} \sigma\left[\left(T_{\mathrm{w}}+273\right)^{2}+\left(T_{\mathrm{g}}+273\right)^{2}\right]\left(T_{\mathrm{w}}+T_{\mathrm{g}}+546\right) \\
& \varepsilon_{\text {eff }}=\left(\frac{1}{\varepsilon_{\mathrm{w}}}+\frac{1}{\varepsilon_{\mathrm{g}}}-1\right)^{-1} \\
& h_{\mathrm{ev}, \mathrm{w}-\mathrm{g}}=0.01623 h_{\mathrm{c}, \mathrm{w}-\mathrm{g}}\left(\frac{P_{\mathrm{w}}-P_{\mathrm{g}}}{T_{\mathrm{w}}-T_{\mathrm{g}}}\right) \\
& h_{\mathrm{c}, \mathrm{w}-\mathrm{g}}=1.22\left(\frac{k_{\mathrm{v}}}{d}\right)\left(G r^{\prime} \operatorname{Pr}_{\mathrm{v}}\right)^{0.22} \\
& G r^{\prime}=\frac{\beta_{\mathrm{v}} g d^{3} \rho_{\mathrm{v}}^{2} \Delta T^{\prime}}{\mu_{\mathrm{v}}^{2}} \\
& \Delta T^{\prime}=\frac{\left(T_{\mathrm{w}}-T_{\mathrm{g}}\right)+\left(P_{\mathrm{w}}-P_{\mathrm{g}}\right)\left(T_{\mathrm{w}}+273\right)}{\left(268.9 \times 10^{3}-P_{\mathrm{w}}\right)} \\
& P_{\mathrm{w}}=\exp \left(25.317-\frac{5144}{T_{\mathrm{w}}+273}\right) \\
& P_{\mathrm{g}}=\exp \left(25.317-\frac{5144}{T_{\mathrm{g}}+273}\right)
\end{aligned}
$$




$$
\begin{gathered}
\operatorname{Pr}_{\mathrm{v}}=\frac{\mu_{\mathrm{v}} C_{\mathrm{v}}}{k_{\mathrm{v}}} \\
T_{\mathrm{i}}=\frac{T_{\mathrm{w}}+T_{\mathrm{g}}}{2} \\
\rho_{\mathrm{v}}=\frac{353.44}{T_{\mathrm{i}}+273} \\
C_{\mathrm{v}}=999.2+0.1434 T_{\mathrm{i}}+1.0101 \times 10^{-4} T_{\mathrm{i}}^{2}-6.7581 \times 10^{-8} T_{\mathrm{i}}^{3} \\
k_{\mathrm{v}}=0.0244+0.7673 \times 10^{-4} T_{\mathrm{i}} \\
\beta_{\mathrm{v}}=\frac{1}{T_{\mathrm{i}}+273} \\
h_{\mathrm{fg}}=2.4935\left(10^{6}-947.79 T_{\mathrm{i}}+0.13132 T_{\mathrm{i}}^{2}-0.0047974 T_{\mathrm{i}}^{3}\right) \text { for } T_{\mathrm{i}} \leq 70 \\
h_{\mathrm{fg}}=3.1615\left(10^{6}-761.6 T_{\mathrm{i}}\right) \text { for } T_{\mathrm{i}}>70
\end{gathered}
$$

